\title{
A DEMONIZAÇÃO DA MULHER QUE, NOS IMAGINÁRIOS DE UMA SOCIEDADE PATRIARCAL, MATA O MARIDO EM CONSEQUÊNCIA DE AGRESSÕES E ABUSOS: LEGÍTIMA DEFESA PUTATIVA
}

Manoela de Paula Baldo

ISSUE DOI: $10.21207 / 1983.4225 .293$

\section{RESUMO}

A presente pesquisa tem como objetivo discorrer e se aprofundar num assunto que sempre foi tabu perante a sociedade e que, ao longo dos tempos, foi se escancarando e tomando lugar para discussão, tanto no âmbito social e moral como no jurídico. A demonização da mulher que assassina o marido por motivos diversos é um assunto que causa incômodo e que foi bem detalhado nesse trabalho, visando a demonstrar todos os lados dessas situações e a elaborar uma tese mais consistente. A meta principal deste trabalho foi confrontar opiniões, doutrinas e julgados, visando à melhor compreensão do tema. Para alcançar esses objetivos, pretendeu-se fazer um estudo na área do Direito Penal e dos demais institutos jurídicos que estejam relacionados a tal assunto, evidenciando a natureza da legítima defesa putativa e a Lei Maria da Penha. A metodologia utilizada para chegar às conclusões impugnadas foi uma busca por artigos, doutrinas e 
literatura jurídica disponível que tratem sobre o tema em questão, pois só assim conseguiu-se reunir opiniões diversas para concretizar tal objetivo. Além disso, fez-se uma grande pesquisa geral na mídia, que incluiu revistas, jornais e sites, para conseguirmos analisar os casos mais relevantes já ocorridos mundialmente relacionados ao tema.

Palavras-chave: Violência doméstica; Mulher assassina; Legítima Defesa Putativa; Transtorno Psiquiátrico; Imputabilidade.

\section{INTRODUÇÃO}

Geralmente debatemos sobre a violência doméstica advinda do lado masculino, quando o homem mata ou agride a mulher por fatos diversos. Essa violência que, a cada dia, ganha mais pauta no mundo moderno e no Brasil, tem conquistado um âmbito extenso, com atualizações constantes à famosa Lei Maria da Penha (Lei n ${ }^{\circ} 11.340$, de 7 de agosto de 2006), graças à grande incidência desse tipo de crime no círculo familiar. Em contrapartida ao citado acima, temos que analisar fatos que têm ocorrido desde os primórdios, mas que não costumam ser estudados a fundo.

Historicamente, a mulher é tachada de "sexo frágil" e, quando comete crimes violentos, costuma chocar a sociedade. Em uma sociedade patriarcal, quando a mulher age fora das grades utopicamente impostas, é demonizada; é o caso da esposa que assassina o cônjuge em situações em que ele não a está agredindo prontamente e nem na iminência de fazê-lo, mas, mesmo assim, a mulher acredita em uma futura agressão e acaba por matá-lo. Há muitos argumentos a serem estudados nesses casos e iremos analisá-los detalhadamente ao longo da pesquisa.

O principal plano dessa pesquisa é estudar as justificativas e causas desses assassinatos e analisar se essa crítica societária se fundamenta em todos esses casos, se ela se justifica em todos esses crimes, pois em vários destes as mulheres se baseiam em agressões que já vêm sofrendo. Além disso, contextuaremos a legítima defesa putativa, que já serviu de justificativa concreta para determinados casos em que a mulher age desta forma. Nesse contexto estudaremos julgados, tanto nacionais como internacionais, aqueles que tiveram maior repercussão midiática. Levaremos nossa discussão a um contexto histórico que mundialmente tem tachado a figura feminina de demoníaca pela forma com que comete esse tipo de crime. 
A escolha deste tema está ligada ao comparecimento a uma palestra no ano de 2013, na Universidade de Coimbra, Portugal, que discorreu sobre o assunto. A palestra foi ministrada pela investigadora do Centro de Estudos Sociais e Professora auxiliar do Departamento de Línguas, Literaturas e Culturas da Faculdade de Letras da Universidade de Coimbra, Adriana Bebiano. Desde então, o tema se tornou foco desta pesquisa.

\section{A SOCIEDADE PATRIARCAL E SEUS MODELOS TAXATIVOS FEMININOS AO LONGO DOS SÉCULOS}

Este capítulo terá como função principal alertar o leitor sobre a opressão histórica que a mulher vive, não só no Brasil como em todo o mundo. Hoje, mesmo com tantas mudanças e tamanha inclusão, o ser feminino ainda é enxergado como mais frágil e por muitas vezes inferior ao homem, o que nos mostra que essa ideologia patriarcal ainda existe e é dominante em praticamente todo o mundo. Mesmo os países mais desenvolvidos, socialmente falando, ainda carregam esse modelo estereotipado da mulher, fazendo com que ela ainda sofra com o preconceito em vários âmbitos: político, econômico, social e outros.

Alguns estudos comprovam que, nos primórdios, homens e mulheres eram vistos como iguais, viviam em uma sociedade onde não era necessário demonstrar superioridade de um em relação ao outro, pois ambos os sexos agiam em grupo, cada um com sua contribuição pessoal para que todos crescessem e sobrevivessem em conjunto.

Porém, com o desenvolver dos séculos e com as formações sociais, esse contexto mudou e os gêneros foram se afastando e procurando cada um por suas vantagens individuais.

Grande exemplo de tudo isso, e uma das bases para a dissertação desse capítulo, é a obra de Lygia Fagundes Telles, na qual a autora expõe a vida cotidiana de três meninas: Lorena, Ana Clara e Lia. As três, ao longo da narrativa, fogem dos modelos tradicionais femininos, pois têm pensamentos evoluídos para a década que a obra retrata (anos 1970).

A importância atribuída a esta obra se dá porque a mesma evidencia o que muitas mulheres procuram fazer, bem como os modos como tentam agir diariamente para driblar o patriarcado dominante, buscando mudanças que realmente representem a forma como querem estar na sociedade, o patamar que querem ocupar. 


\subsection{A opressão histórica das mulheres}

Em meio a essa sociedade exposta anteriormente, a mulher sempre é fragilizada e condenada, pois não se vê na figura do homem o culpado. Na ideologia machista, aquela mulher que sofria abusos do marido deveria aguentar tudo sem tomar atitude, pois é seu dever como esposa suportar as exigências do marido. Há ainda outra justificativa absurda, a qual afirma que mulheres que sofrem abusos e violências são as culpadas por isso, pois intrigaram seus companheiros a agir dessa forma.

Com o afastamento daquela ideia de favorecimento do grupo citada anteriormente nos primórdios da nossa sociedade, passamos a enfrentar a individualização dos gêneros, e com ela veio a opressão da mulher e a designação de suas "tarefas" diante da hierarquia formulada pelos homens.

A primeira figura feminina de que se tem notícia é Eva, de acordo com a Bíblia Sagrada. E a partir dela já se evidencia na religião católica a inferioridade da mulher perante o homem. Na história descrita na Bíblia, Eva come do fruto proibido e o oferece a Adão que, comendo dele, influenciado negativamente por Eva, acaba conhecendo o pecado. A partir de então, o destino da mulher estava cerrado sobre a Terra: "Eu multiplicarei os trabalhos dos teus partos. Tu parirás teus filhos em dor, e estará debaixo do poder de teu marido, e ele te dominará". 224

Após a exposição desta primeira figura feminina, podemos partir para as civilizações que temos por base. A Grécia Antiga é um dos maiores exemplos de sociedade patriarcal e superioridade masculina. Segundo Natália Ruela:

A mulher grega dispunha do mesmo desprestígio que o escravo: ambos realizavam apenas trabalhos manuais e a única função que divergia as mulheres desses seres, que eram a representação da mais baixa escala da sociedade, era a maternidade. Contudo, além de gerar filhos, era responsabilidade da mulher tudo que fosse necessário para a subsistência do homem, como o plantio e a alimentação. Assim, de acordo com os gregos, os deuses criaram as

${ }^{224}$ SAGRADA, Bíblia. Gênesis (3, 16). 1989. 
mulheres para as funções do lar a o homem para pensar e para lutar. ${ }^{225}$

Na mitologia grega, deu-se a criação de Pandora e, com ela, outra evidência do quanto a figura feminina foi interpretada de forma banal nessa sociedade. A primeira mulher criada pelos deuses era mau-caráter e foi enviada por eles com a intenção de trazer a discórdia, de castigar os homens terráqueos ${ }^{226}$. Portanto, não há mais o que se falar em relação a quanto a mulher era vista com indiferença perante a cultura grega e o quanto era inferiorizada, além do que a distância entre os gêneros era evidente.

Para não falar de uma só cultura base, ao expor a civilização romana também enxergamos claras situações em que a mulher era tida como inferior ao homem. Lá foi criado o instituto chamado paterfamílias, expressão em latim, que significa, literalmente, "pai de família". Esse instituto, como o nome já indica, tinha a intenção de designar ao pai a palavra final e o poder de mando sobre todo o seio familiar (mulher e filhos), além de seus escravos; portanto, estes deviam respeito a ele. ${ }^{227}$

\subsection{A luta feminina contra o patriarcado}

Há muitos momentos históricos de mulheres lutando contra os limites impostos pela sociedade patriarcal. Foram essas lutas que as presentearam com o que têm hoje pois, mesmo não sendo valoradas igualmente perante os homens na maioria das culturas, ainda assim conseguiram conquistar muito espaço.

Uma importante figura feminina nesse sentido foi a italiana Christine de Pizan, uma poetisa que viveu na sociedade francesa no século XIV, a qual lutava pelos direitos das mulheres e foi considerada a pioneira nessa luta por meio de sua escrita.

\footnotetext{
${ }^{225}$ RUELA, Natália. Feminismo e Construção de Identidades Femininas: As Meninas de Lygia Fagundes Telles. Universidade Estadual do Marigá, 2009. p. 18.

226 VERNANT, Jean Pierre. O Universo, Os Deuses, Os homens. Tradução: Rosa Freire D’Aguiar - São Paulo. Companhia das Letras, 2000. p. 69.

227 ALVES, Branca Moreira; PITANGUY, Jacqueline. O que é feminismo. Coleção Primeiros Passos. São Paulo: Editora Brasiliense, 1981. p. 15.
} 
"A escritora é considerada a autora do primeiro tratado feminista, A Cidade das Mulheres, que refutava as ideias que defendiam a inferioridade do sexo feminino e a diferença penal entre crimes cometidos por homens e por mulheres." 228

A importância na citação de Pizan nesta pesquisa é focada na sua contribuição ao discutir as penas impostas antigamente a homens e mulheres e a discrepância que prevalecia entre estas. No pensamento da antiguidade, a mulher que cometia um crime tinha que ser punida de forma muito mais severa e longa do que um homem pois, como já dito anteriormente, o homem é considerado o ser forte e superior, portanto, suas razões ao cometer algum crime, eram muito mais compreensíveis do que as de uma mulher, que era uma simples submissa a esse poder soberano dos homens.

Não se pode esquecer um dos maiores genocídios da história da humanidade, qual seja a Inquisição, que teve início com uma rebeldia de mulheres tentando mostrar seus conhecimentos, podendo se igualar aos homens em vários aspectos, ou até mesmo se superiorizar perante eles, mas que acabaram por promover uma chacina de seu gênero na Idade Média.

"As maiores vítimas, acusadas e queimadas como bruxas, eram as mulheres que possuíam os conhecimentos que escapavam ao domínio masculino; a cada dez mulheres queimadas, apenas um homem o era." 229

O que ocorreu nessa época foi que as mulheres desde sempre foram conhecedoras dos poderes medicinais das plantas pois, por necessidade, eram parteiras, curandeiras, entre outros tipos de funções, que acabavam por exigir que dominassem essas técnicas, já que ainda não se tinha conhecimento científico de remédios. A partir do momento em que surgiu o estudo da Medicina, obviamente que somente por homens, todas essas mulheres que dominavam as antigas técnicas de curandeirismo popular acabaram por serem tachadas de bruxas por as utilizarem para as tarefas diárias, que sempre foram comuns às famílias mais populares. A partir de então, foram perseguidas, torturadas e, na maioria das vezes, mortas.

${ }^{228}$ RUELA, Natália. Feminismo e Construção de Identidades Femininas: As Meninas de Lygia Fagundes Telles. Universidade Estadual do Marigá. 2009. p. 21.

229 ALVES, Branca Moreira; PITANGUY, Jacqueline. O que é feminismo. Coleção Primeiros Passos. São Paulo: Editora Brasiliense, 1981. p. 20. 
Se hoje queimamos as bruxas, é por causa de seu sexo feminino [...] A mulher é mais carnal que o homem; vemos isto por suas múltiplas torpezas... Existe um defeito na formação da primeira mulher, pois ela foi feita de uma costela curva, torta, colocada em oposição ao homem. Ela é, assim, um ser vivo imperfeito, sempre enganador. ${ }^{230}$

$\mathrm{Na}$ contemporaneidade, entre as décadas de 30 e 40, a mulher finalmente começou a sair da inércia e se tornar digna de algumas regalias masculinas, como o voto e leis constitucionais, que passaram a reconhecê-la como cidadã. Isso decorreu do início da temporada de guerras mundiais, em que os homens se viram obrigados a abandonar o lar e lutar, o que contribuiu para que as mulheres ocupassem esse lugar, forçadamente.

\section{ASPECTOS DOUTRINÁRIOS E JURISPRUDENCIAIS QUE AUXILIAM NA DEFINIÇÃO DA LEGÍTIMA DEFESA PUTATIVA}

Neste capítulo em questão, analisar-se-ão dois tipos de situações da legítima defesa, aquela em que a mulher estava sendo agredida no momento em que cometeu o homicídio, mas acabou por exceder os limites da lei; e aquela em que a mulher não estava sendo agredida no momento do crime, mas por ter sofrido esses abusos por tantas vezes, acabou crendo que estava sofrendo a agressão ou que estava na iminência desta, mesmo não o estando.

\subsection{Definições da legítima defesa}

A legítima defesa, dentre outras, como estado de necessidade, estrito cumprimento do dever legal e exercício regular de direito, é forma de exclusão da ilicitude. Ilicitude, segundo Fernando Capez "é a contradi-

230 SPRENGER, Jacques. Malleus maleficarum: manual de base do caçador de bruxas. Final do séc. XV. In ALVES, Branca Moreira. p. 24. 
ção entre a conduta e o ordenamento jurídico". Portanto, se aquele que cometer o delito expresso no nosso Código Penal se enquadrar em alguma causa excludente da ilicitude, estará isento de pena.

Sobre o conceito de legítima defesa, percebe-se que a intenção do Estado ao criar esta discriminante foi muito interessante: "o Estado não tem condições de oferecer proteção aos cidadãos em todos os lugares e momentos, logo, permite que se defendam quando não houver outro meio." 231

O principal conceito de legítima defesa está elencado em nosso Código Penal Brasileiro. Vejamos: "Art. 25. Entende-se em legítima defesa quem, usando moderadamente dos meios necessários, repele injusta agressão, atual ou iminente, a direito seu ou de outrem.”.

Esse contexto vem sendo interpretado por doutrinadores, como é o caso de Alexandre Araripe e André de Freitas, que nos trazem um conceito um pouco mais abrangente:

Decorre a legítima defesa, basicamente, de uma permissão do Estado, melhor dizendo, de uma preservação, pelo Estado, do direito de autodefesa do cidadão. Em principio, somente o Estado pode reagir contra atos de agressão; é permitido ao cidadão exercer a autodefesa, nos limites do necessário para repelir o ataque e salvar o bem jurídico. ${ }^{232}$

A partir desses conceitos, a doutrina passa a explicitar cada requisito para a concretude da legítima defesa, pois para ela realmente ocorrer, a situação precisa se encaixar fielmente à descrita, ou então será desconsiderado o instituto e a pessoa deverá responder pela ilicitude do ato sem nenhuma excludente.

Historicamente, a legítima defesa era referenciada em várias legislações, como o Código de Manu, na Lei Mosaica, nas Leis atenienses de Sólon, na Lei das Tábuas, entre outras na antiguidade; além de ser

\footnotetext{
${ }^{231}$ CAPEZ, Fernando. Curso de Direito Penal: parte geral (arts. $1^{\circ}$ a 120 ) - 11. ed. rev. e atual. São Paulo: Saraiva, 2007. p. 281. v. 1.
}

${ }^{232}$ MARINHO, Alexandre Araripe, FREITAS, André Guilherme Tavares de. Manual de Direito Penal: parte geral. Rio de Janeiro: Lumen Júris, 2009. p. 248. 
vista também na Índia, Roma e Grécia, que previam a defesa da própria vida e da honra, evidenciando assim a legítima defesa. ${ }^{233}$

\subsection{Legítima defesa putativa} Damásio.:

Como conceito da legítima defesa putativa tem-se, segundo

Há legítima defesa putativa quando o agente, por erro de tipo ou de proibição plenamente justificado pelas circunstâncias, supõe encontrar-se em face de agressão injusta [...] o agente supõe a existência da agressão ou sua injustiça, respectivamente, erro sobre a situação de fato ou sobre a injustiça da agressão[... $]^{234}$

Como analisado anteriormente, a legítima defesa putativa é um instituto um tanto quanto incomum, por isso é uma das variações da legítima defesa. Está claro que ele ocorre por um engano da mente humana, que acredita estar sendo agredida, ou na iminência disto, e acaba se defendendo de um perigo que na verdade nunca ocorreu. $\mathrm{O}$ que ocorre são os chamados erro de tipo e erro de proibição.

Ocorre o erro de tipo quando o agente não sabe que está cometendo um crime, mas acaba por praticá- $\mathrm{lo}^{235}$.

Quando o agente tem perfeita noção do que está fazendo, mas não tem conhecimento de que aquilo seja vedado pela lei e acredita que a conduta que está proibida na lei, na verdade é permitida, acaba caindo no erro de proibição.

Para auxiliar no entendimento expõe-se a jurisprudência abaixo:

TJ-ES - ACR: 24050216563 ES 24050216563, Relator: NEY BATISTA COUTINHO Data de

\footnotetext{
${ }^{233}$ MARINHO, op. cit., p. 248.

234 JESUS, Damásio de. Direito penal: parte geral. 32. ed. São Paulo: Saraiva, 2011. p. 438. v. 1 .

${ }^{235}$ CAPEZ, op. cit., p. 220.
} 
Julgamento: 01/02/2012, PRIMEIRA CÂMARA CRIMINAL, Data de Publicação: 10/02/2012. APELAÇÃO CRIMINAL - HOMICÍDIO QUALIFICADO (ART. 121, 20, I E IV, DO CP)DESCLASSIFICAÇAO PARA HOMICÍDIO CULPOSO (ART. 121, 3, DO CP)- LEGÍTIMA DEFESA PUTATIVA - ERRO DE TIPO INESCUSÁVEL - DECISÃO AMPARADA EM UMA DAS VERSÕES SUSTENTADAS EM PLENÁRIO - SUSPENSÃO CONDICIONAL DO PROCESSO - RECURSO DESPROVIDO SENTENÇA ANULADA, DE OFÍCIO. A disposição normativa prevista no art. 593, inciso III, d, do Código de Processo Penal, disciplina o cabimento de apelação em face da decisão dos jurados manifestamente contrária à prova dos autos, sendo certo, consoante o magistério doutrinário e jurisprudencial, que se trata da hipótese mais controversa e complexa, por ser comum que, em muitos casos, haja nítida afronta ao princípio constitucional da soberania dos veredictos. A despeito dos argumentos lançados pelo Ministério Público Estadual, certo é que os jurados, respaldados pelo sistema probatório da íntima convicção, concluíram que o apelado incorreu em conduta típica, ilícita e culpável, porém agindo em legítima defesa putativa (também intitulada doutrinariamente como erro de tipo permissivo - aquele que incide sobre os pressupostos fáticos de uma causa de justificação), de sorte que, por ser inescusável derivado de culpa - ensejou a desclassificação do delito de homicídio qualificado (art. 121, $2^{\circ}$, IV, do CP) para homicídio culposo (art. 121, 30, do CP) $[\ldots]^{236}$

Em suma, o instituto da legítima defesa putativa se mostra bastante complicado de ser aceito diante dos tribunais, principalmente no tribunal do júri, que demonstra pouca aceitação de suas justificativas.

\footnotetext{
236 Disponível em: <http://tj-es.jusbrasil.com.br/jurisprudencia/21397672/apelacao -criminal-acr-24050216563-es-24050216563-tjes>. Acesso em: 06 abr. 2015.
} 
Àqueles que se predispõem a defender a tese, é necessário encontrar argumentos extremamente consistentes para tê-la acolhida.

\subsection{Excesso na legítima defesa}

O parágrafo do artigo exposto anteriormente, que elenca as causas excludentes da ilicitude, sanciona aquele que age com excesso em uma delas: "Art. 23. Parágrafo único. O agente, em qualquer das hipóteses deste artigo, responderá pelo excesso doloso ou culposo".

A trajetória histórica desse parágrafo é um pouco longa e complexa. Só no ano de 1935 é que o excesso na legítima defesa começou a ser previsto pela legislação brasileira, e mesmo assim, em um projeto de lei, qual seja o Projeto de Lei Virgílio de Sá Pereira, que não foi aprovado.

Então, em 1940, com o advento do Código Penal brasileiro, o excesso passou a ser elencado no parágrafo do art.21, que previa a legítima defesa. Porém, somente na modalidade culposa, e ainda sim, unicamente para a legítima defesa, pois as outras espécies de excludentes ainda não eram previstas. Em 1969 ele passou a valer para todas elas.

Finalmente, graças à inclusão feita pela Lei 7.209, de 11 de julho de 1984, o excesso passou a valer nas duas modalidades - culposa e dolosa $-\mathrm{e}$, inclusive, para todas as excludentes. Seu texto está no artigo 23, parágrafo único, acima exposto, e vigora até os dias atuais.

\section{3 \\ O ENQUADRAMENTO DA MULHER ASSASSINA NA INIMPUTABILIDADE POR TRANSTRONO PSIQUIÁTRICO}

Uma das principais funções da pesquisa é discutir e elencar algumas das causas que levaram essas mulheres a cometerem crimes tão bárbaros e também formular questões para os estudiosos, com o fim de decidir qual o tipo de pena é cabível a essas mulheres.

\subsection{Transtornos psiquiátricos cabíveis}


Após ter-se analisado vários tipos de transtornos psiquiátricos, acaba-se identificando a neurose como o mais próximo das nossas "pseudo-criminosas". "Neuroses são transtornos da afetividade que levam as pessoas a experimentar sentimentos e reações motoras incomuns e/ou incontroláveis, com perfeita conservação do juízo de realidade."237

Ante o exposto, conclui-se que, no caso desse transtorno mental, a pessoa não confunde a realidade, pois tem perfeita consciência do que está ocorrendo à sua volta. Na maioria dos outros casos de transtornos, ocorre o contrário, já que o indivíduo distorce a realidade e acaba agindo de forma totalmente inconsciente e inesperada; é isso que difere a pessoa neurótica das outras com outros tipos de transtornos mentais. A neurose está muito mais ligada ao ambiente em que a pessoa se encontra e às situações vividas do que a algum problema mental efetivo; é uma doença bastante relacionada ao lado emocional da pessoa afetada.

Há cinco tipos de estruturas neuróticas mais citadas em pesquisas. São elas: neurose de angústia, neurose obsessiva, neurose histérica, neurose fóbica e neurose depressiva.

A neurose de angústia está ligada a situações vividas no passado ou no presente pelo indivíduo que apresenta seus sintomas. A pessoa apresenta um sentimento de angústia não muito explicativo e, na maioria das vezes, não sabe o que o causa, porém, graças a ele, pode apresentar surtos a qualquer momento, sem ao menos saber o porquê.

Agora precisamos situar esse transtorno no agente em si, ou seja, na conduta criminosa que estamos estudando. De acordo com Sampaio Filho,

[...] ]entende-se por delinquência neurótica a conduta criminosa decorrente da manifestação dos conflitos internos do sujeito consigo mesmo. O criminoso pratica o delito e tem consciência total ou parcial de que será punido por isso. A sanção serviria para aplacar-lhe a culpa e reduzir o conflito interno primário anterior. ${ }^{238}$

\footnotetext{
237 Disponível em:<http://www.abc.med.br/p/psicologia..47.psiquiatria/220200/neuroses+ o+que+saber+basicamente+sobre+elas.htm>. Acesso em: 05 dez. 2014.

${ }^{238}$ FILHO, Nestor Sampaio Penteado. Manual Esquemático de Criminologia. 2. ed. São Paulo: Saraiva, 2012. p. 170.
} 
Isso nos remete totalmente ao conceito de neurose dito anteriormente, pois a pessoa tem consciência dos atos e das sanções que está praticando. Além disso, na maioria dos casos, tem também a intenção de fazê-lo, pois vive perante a realidade. Porém, age em função de um conflito interno que só poderá ser explicado pelos médicos peritos a partir de uma análise detalhada da mulher em questão, isto é, uma análise das causas desde sua infância.

\subsection{Prova pericial}

Estão elencados no Código de Processo Civil Brasileiro os meios de prova no processo. São eles: o depoimento pessoal (Art. 342 a 347), a exibição de documentos ou coisa (Art. 355 a 363), a prova documental (Art. 364 a 399), a confissão (Art. 348 a 354), a prova testemunhal (Art. 400 a 419), a inspeção judicial (Art. 440 a 443) e a prova pericial (Art. 420 a 439).

Como vemos, a prova pericial é um dos meios legais de prova e tem o objetivo de ajudar no processo, bem como de tentar demonstrar fatos que, unidos ao processo, ajudarão o juiz a chegar às suas conclusões. O Código de Processo Civil elenca e caracteriza a prova pericial, porém estudaremos a perícia no Código de Processo Penal, pois é o ramo que mais se encaixa em nossa pesquisa.

De acordo com Washington dos Santos, perícia é "procedimento de investigação, feita por pessoa habilitada, que visa a provar, através de exame, vistoria e avaliação, de caráter técnico e especializado, esclarecendo um fato, um estado ou estimação da coisa que é objeto de litígio, ou processo" 239 .

Ao explorar o conceito de perícia, concluímos que esse é o melhor e mais usado método para conseguirmos definir o estado mental de nossa criminosa. Para qualificarmos melhor esse assunto e esclarecermos minunciosamente nossas dúvidas, adentraremos um pouco no estudo da psicopatologia forense, que é "o ramo da Medicina Legal que estuda as doenças, as deficiências e os distúrbios de natureza mental"240.

\footnotetext{
${ }^{239}$ SANTOS, Washington dos. Dicionário Jurídico Brasileiro. Belo Horizonte: Del Rey, 2001. p. 186.

${ }^{240}$ Idem. p. 221.
} 


\subsection{Psicopatologia forense}

Segundo Ricardo Bina, perito é "o indivíduo que possui conhecimentos técnicos e especializados em determinada ciência ou atividade, e em razão desse conhecimento, é chamado para intervir num processo." $" 241$

Continuando com a intenção de nossa pesquisa, essa perícia terá grande valor nos nossos casos até então estudados, pois se, de acordo com nosso perito, ficar comprovado que nossa agente sofreu, ou sofre de algum transtorno, isso refletirá imediatamente em sua pena, pois estaremos diante de uma discussão até então não exposta sobre sua capacidade. A partir de então passarão a estudar, no processo, o seu grau de sanidade, para atribuir sua devida imputabilidade.

De acordo com o nosso Código Penal, a inimputabilidade possui três hipóteses: a doença mental, o desenvolvimento mental incompleto e o desenvolvimento mental retardado.

Partindo desse pressuposto legal, o perito analisará o agente do crime e imputará a ele a hipótese em que ele se encaixa, lembrando que nossa agente poderá também não se encaixar em nenhuma delas. Aos que se declararem inimputáveis ou semi-imputáveis, se aplicará a medida de segurança.

Segundo a Medicina Legal, as psicopatologias são classificadas em um grupo de cinco, sendo elas: oligofrenias, epilepsia, neuroses, psicopatias e psicoses. Podemos ver aqui que nosso principal transtorno estudado anteriormente é perfeitamente cabível nesse tipo de perícia. Nosso perito analisará o agente e o classificará.

\subsection{Medida de segurança}

Temos falado e detalhado desde o começo deste capítulo um possível transtorno cabível em nossa agente. Se diagnosticada com esse transtorno, caberá então ao juiz decidir sobre sua sanção. Nosso Código prevê aos declarados inimputáveis a medida de segurança; aos semiimputáveis, a medida de segurança ou a pena, que deverá ser recomendada pelo perito, que é a pessoa mais indicada para tal recomendação, visto

${ }^{241}$ BINA, Ricardo. Medicina Legal. 2. ed. São Paulo: Saraiva, 2009. p. 25. 
que o juiz será possivelmente um leigo no assunto; e aos imputáveis, a pena.

A medida de segurança, apesar do nome literal não nos remeter a isso, é uma sanção, e tem uma função preventiva, ou seja, de precaução. Para Capez, isso se justifica "no sentido de evitar que o autor de uma infração penal que tenha demonstrado periculosidade volte a delinquir". 242

De acordo com Mirabete, tal medida, "embora mantenha uma semelhança com a pena, diminuindo um bem jurídico, visa precipuamente à prevenção, no sentido de preservar a sociedade da ação de delinquentes temíveis e de recuperá-los com tratamento curativo". 243

Analisando os conceitos acima, chegamos à conclusão de que a medida de segurança não visa a punir o agente, pois, na maioria das vezes, ele é incapaz e quase sempre inconsciente de seus atos infratores, os quais nossa sociedade repudia, mas sim prevenir que outro ato semelhante ocorra e evitar que a sociedade seja lesada novamente por este agente.

Segundo nosso Código Penal, há duas espécies de medida de segurança: a detentiva e a restritiva. O art. 97 prevê que, "se o agente for inimputável, o juiz determinará sua internação (art. 26). Se, todavia, o fato previsto como crime for punível com detenção, poderá o juiz submetê-lo a tratamento ambulatorial.”.

\section{$4 \quad$ CASOS PRÁTICOS E DECISÕES PROFERIDAS}

Manchetes relacionadas ao tema não são nem um pouco difícil de serem encontradas, pois as mulheres vêm sofrendo agressões ao longo de muitos anos e as sanções que deveriam ser impostas aos agressores não têm tido efeito e por vezes não têm nem ocorrido, já que na maioria das denúncias feitas por essas mulheres nenhuma atitude é tomada por parte da polícia.

Veremos a seguir algumas situações e, como as próprias notícias descrevem em praticamente todos os casos, as mulheres já fizeram

\footnotetext{
${ }^{242}$ CAPEZ, Fernando. Curso de Direito Penal: parte geral (arts. $1^{\circ}$ a 120 ). 11 . ed. rev. e atual. São Paulo: Saraiva, 2007. p. 429. v. 1.

${ }^{243}$ MIRABETE, Julio Fabrini. FABRINI, Renato N. Manual de Direito Penal, volume 1: parte geral, arts. $1^{\circ}$ a 120 do CP. 30. ed. São Paulo: Atlas 2014. p. 355.
} 
denúncias e boletins de ocorrência dos abusos que sofrem. Porém, como não havia provas dos fatos alegados, quase nunca o agressor era preso e as mulheres acabavam sendo agredidas novamente.

A famosa expressão: "fazer justiça com as próprias mãos" toma sua forma nesse momento. A mulher, esgotada por sofrer tanto nas mãos do companheiro e por não encontrar seu amparo na justiça - amparo que deveria ser oferecido -, acaba agindo de uma maneira que excede os limites da lei. Para se proteger e/ou proteger seus filhos dos constantes ataques, toma uma atitude drástica e mata seu algoz.

Há situações em que as mulheres se encaixam nas descriminantes anteriormente descritas e aí caberá ao juiz ou tribunal do júri decidir sobre a penalidade a ser aplicada, podendo até mesmo a agente ser absolvida, caso esteja evidente seu cabimento em uma das excludentes.

Uma coisa importante a ressaltar é a de que situações como o crime passional não devem ser confundidas com o tema que é foco desta pesquisa.

\subsection{Casos de maior relevância nacional e internacional}

Antes de expor os casos mais relevantes propriamente ditos, vejamos manchetes que se encaixam em nosso tema e demonstram o quanto esse tipo de situação é incidente em nosso cotidiano: "Mulher mata o marido com fio de ferro de passar roupa em São Vicente"244; "Mulher reage durante agressão, mata o marido e foge com ajuda de vizinhos"245; "Mulher que sofria violência doméstica mata o marido queima-

\footnotetext{
244 Disponível em: <http://www.atribuna.com.br/noticias/noticias-detalhe/policia/mulhermata-o-marido-com-fio-de-ferro-de-passar-roupa-em-saovicente/?cHash=61968d6c01c7b0e63b3d04b6884c3512>. Acesso em 27 jul. 2015.

245 Disponível em: <http://g1.globo.com/sp/santos-regiao/noticia/2015/06/mulher-reagedurante-agressao-mata-o-marido-e-foge-com-ajuda-de-vizinhos.html >. Acesso em: 28 jul. 2015.
} 
do em Ipira"246; "Mulher que matou marido após ser espancada recebe apoio de outras vítimas" 247 .

Só nestes cinco exemplos, podemos ver o quanto tem se tornado incidente esse tipo de crime. Todas essas são manchetes do primeiro semestre do ano de 2015.

Inicia-se a análise dos casos por uma situação ocorrida no Brasil, mas que acabou ficando bastante conhecida devido à sua barbárie. $\mathrm{O}$ homicídio aconteceu em Conceição das Alagoas, interior do Estado de Minas Gerais:

Na tarde desta última quarta-feira (17), no Triângulo Mineiro, em Conceição das Alagoas $(538 \mathrm{~km}$ de Belo Horizonte), foram encontrados dentro de uma fossa partes de um corpo humano[...]

A esposa da até então suposta vítima chegou a dizer para uma cunhada que o marido havia viajado e depois disso também sumiu.

Os familiares do homem desaparecido estiveram na casa e abriram a tampa da fossa que tem pouco mais de 1 metro e 60 centímetros de profundidade e lá foram encontrados as pernas e o tronco do corpo[...] Após ser emitido um mandado de prisão para Odete Maria, de 69 anos, esposa da vítima, Policiais Civis encontraram a mulher em Uberaba, escondida na casa de uma amiga.

Após a prisão, Odete acabou confessando o crime e levou os policiais até o local onde havia jogado as demais partes do corpo do marido[... $]^{248}$

\footnotetext{
246 Disponível em: <http://www.ndonline.com.br/florianopolis/noticias/33355-mulherque-sofria-violencia-domestica-mata-o-marido-queimado-em-ipira.html>. Acesso em: 28 jul. 2015.

${ }^{247}$ Disponível em: <http://www.pragmatismopolitico.com.br/2015/07/mulher-que-matoumarido-apos-ser-espancada-recebe-apoio-de-outras-vitimas.html >. Acesso em: 01 ago. 2015.

${ }^{248}$ Disponível em: <http://www.portilhoonline.com.br/noticias-regionaisem-minas-geraismulher-mata-o-marido-esquarteja-e-joga-os-restos-dentro-de-uma-fossa-mae-vai-buscarfilho-de-05-meses-em-creche-particular-de-caldas-novas-e-recebe-crianca-cheia-d/> .
} Acesso em: 30 jul. 2015. 
Como visto acima, a mulher agiu de forma bastante excessiva ao matar e esquartejar o marido.

Uma das maiores provas de que esse homicídio foi por desespero é quando se vê que a mulher não se arrepende do que fez, e isso demonstra claramente todo o peso que tinha sobre suas costas e como a morte do marido foi sua libertaçãofrente aos abusos constantes que sofria.

Outro caso de grande repercussão foi um ocorrido em Portugal, na cidade do Porto:

Após 40 anos de maus tratos, Maria Clementina Pires matou o marido com um machado de cozinha. Ontem, a mulher de 63 anos foi absolvida pelo Tribunal de S. João Novo, no Porto, uma decisão aplaudida em plena sessão pela meia centena de pessoas que encheram a sala. $\mathrm{O}$ juiz-presidente do Colectivo, João Grilo, considerou que ela agiu em legítima defesa e evitou tornar-se mais uma vítima de violência doméstica[...]

$\mathrm{O}$ juiz recordou os números apresentados pela Anistia Internacional que referem que, em Portugal, no último ano, morreram 39 mulheres vítimas de violência doméstica e aproveitou para criticar o novo enquadramento legal dos crimes que deixaram de ser semipúblicos para serem públicos. "Isso para os tribunais vale zero", acrescentou o magistrado, que defendeu a reavaliação do quadro punitivo deste tipo de crime $[. .$.

À saída da sala de audiências, e depois de saudada pelos familiares e amigos, Maria Clementina mostrou satisfação pelo resultado da sentença. "Foram muitos anos de sofrimento e acho que este meu caso pode servir de exemplo a outras mulheres, embora eu considere que o melhor, desde que seja possível, seja a denúncia junto às autoridades", afirmou a idosa. ${ }^{249}$

249 Disponível em: <http://www.dn.pt/inicio/interior.aspx?content_id=658629>. Acesso em: 19 jul. 2015. 
O que mais se percebe nesses casos é que as mulheres agem para defender sua própria vida, pois, ao longo de tantos anos sofrendo, chega um momento em que precisam realmente lutar por suas próprias vidas e, em alguns casos, pela de seus filhos também, como é o caso do homicídio que ocorreu na República Dominicana em 2003:

Uma dominicana que planejou, com a ajuda de sua empregada e dois de seus cinco filhos, o assassinato de seu marido após anos de violentos abusos, já tinha apresentado mais de 100 queixas contra ele na polícia, que não fez nada. Miriam Brito e sua empregada doméstica, Elisa Deidana, que estão detidas à espera de julgamento, mataram José Castro em 25 de novembro passado, com vários tiros, em sua casa em San Cristóbal, oeste de Santo Domingo[...]

Rojas Nina, que faz parte da defesa de Brito, disse que os agentes da Polícia Nacional "nunca deram atenção" às constantes denúncias da vítima. "Deixaram a pobre Miriam sozinha"[... $]^{250}$

Além desta passagem, a notícia ainda esclarece que dois filhos do casal ajudaram a cometer o crime, apesar de os disparos terem sido feitos somente por Deidara. Um ponto muito importante e que deve ser abordado com atenção é o fato de que Deidara tentou sair de casa por muitas vezes, se mudando para vários lugares, inclusive para outros países, com o intuito de fugir de seu marido, porém ela sempre voltava para defender seus filhos, pois sabia do sofrimento que eles passavam na mão do pai.

Houve um caso também na Turquia, País conservador e com tradição de ter suas mulheres maltratadas frequentemente pelos maridos. Uma fala que conta no depoimento da agente reflete o que muitas dessas mulheres têm vontade de dizer. Doğan afirmou: "Será que as mulheres sempre têm que morrer? Deixe alguns homens morrer também. Matei-o

250 Disponível em: <http://noticias.uol.com.br/inter/efe/2003/12/04/ult1807u498.jhtm>. Acesso em: 09 abr. 2015. 
pela minha honra"251. É contagiante ver que essas mulheres necessitam chegar ao extremo dos abusos e agressões e que, sem possuir nenhum amparo do Estado, precisam agir com suas próprias mãos para não serem mais uma vítima da violência doméstica no mundo.

Outro caso bastante famoso e que gerou bastante repercussão ocorreu na China no ano de 2014. Essa repercussão é consequente de o País ser tão conservador, graças a seu regime comunista, mas ter absolvido a agente por agir dessa forma:

PEQUIM (Reuters) - O principal tribunal da China anulou a sentença de pena de morte de uma mulher condenada por matar o marido depois de sofrer anos de violência doméstica[...]

Li, de 43 anos, foi condenada à morte em 2012 pelo assassinato de seu marido. Tan Yong. Tan havia abusado física, sexual e verbalmente de Li por mais de três anos, tendo-a queimado com cigarros e cortado um de seus dedos, disse Guo.

Li espancou o marido até a morte com uma pistola de ar comprimido depois que ele ameaçou atirar nela. Depois, ela cortou o corpo dele e queimou as partes $[\ldots]^{252}$

Vê-se que, sem dúvidas, esse foi outro caso bárbaro, Li Yan cometeu o crime de homicídio em um País que prevê a pena de morte e que tem um sistema penal muito rígido. Porém, o Tribunal entendeu seus motivos e absolveu a autora, demonstrando que ela teve motivos suficientes para agir daquela forma.

Apenas para contextualizar e demonstrar a quantidade de mulheres que passam por essa situação, a ONU fez uma pesquisa e, de acordo com ela, até 2011, 125 países possuíam leis de combate à violência doméstica, sendo o Brasil um dos que possuem uma das leis mais duras, a famosa Lei Maria da Penha. Segundo o site do governo brasileiro sobre esta Lei, em 2012 as Nações Unidas classificaram a Lei nº 11.340/2006 -

${ }^{251}$ Disponível em: <http://www.pragmatismopolitico.com.br/2015/07/mulher-que-matoumarido-apos-ser-espancada-recebe-apoio-de-outras-vitimas.html>. Acesso em: 24 mai. 2015.

252 Disponível em: <http://br.reuters.com/article/worldNews/idBRKBN0EZ1M J20140624>. Acesso em: 08 mar. 2015. 
a chamada Lei Maria da Penha - como a terceira melhor lei do mundo no combate à violência doméstica, perdendo apenas para Espanha e Chile. ${ }^{253}$

Porém, em outros países, essas leis ainda são muito limitadas, pois não abrangem todos os âmbitos dessa violência e ainda deixam muitas mulheres à mercê dos maus-tratos sofridos pelos companheiros. Por exemplo, em vários países, principalmente aqueles de religião muçulmana, o estupro conjugal não é considerado crime, ou seja, a mulher tem que se submeter ao ato sexual com o marido em qualquer circunstância e ele não será punido. Para comprovar, a ONU também fez uma pesquisa em março de 2014, especialmente para analisar os países muçulmanos, e a porcentagem dessa violência e desse desrespeito com relação às mulheres nesses países mostrou que, no Egito, mais de 27 milhões de mulheres tiveram os órgãos genitais mutilados e, no Iraque, mulheres são vendidas e estupradas. ${ }^{254}$

No entanto, é triste ver que, mesmo tendo a terceira melhor lei do mundo, o Brasil ainda tem muitas dificuldades em efetivá-la. Como visto ao longo da pesquisa, as mulheres analisadas ainda são vítimas dessa terrível violência, e justamente por culpa dela é que agem com tanta ira, chegando ao ponto de se tornarem criminosas.

\subsection{Tratamento penal dado às mulheres}

Muitos juízes e tribunais têm entendido que as situações já abordadas neste artigo - legítima defesa putativa, transtorno psiquiátrico, violenta emoção - servem como justificativa para a absolvição dessas mulheres. Neste sentido, o juiz português João Grilo fez ótima declaração, ao mostrar seu perfeito entendimento perante as situações que essas mulheres vivem dentro de casa com seus companheiros por muito tempo: "A senhora, ao longo de 40 anos, sofreu com isto tudo e não era nesta altura que ia chamar a polícia. As pessoas estão em casa, vivem com a agressão e após a queixa é que começa o verdadeiro inferno". ${ }^{255}$

\footnotetext{
253 Disponível em: <http://www.compromissoeatitude.org.br/legislacao-sobre-violenciacontra-as-mulheres-no-mundo/>.-Acesso em: 09 mar. 2015.

254 Disponível em: <http://g1.globo.com/fantastico/noticia/2014/06/mulheres-sao-vistascomo-propriedades-dos-homens-no-libano.html>. Acesso em: 12 abr. 2015.

255 Disponível em: <http://www.dn.pt/inicio/interior.aspx?content_id=658629>. Acesso em: 13 jun. 2015.
} 
Após estudos, conclui-se que um dos Tribunais mais compreensíveis é o português. Juízes portugueses têm cada vez mais entendido que as justificativas são plausíveis para a absolvição da mulher. Sobre isso: "Segundo o coletivo, a mulher matou para defender a sua vida e as dos dois filhos menores do casal. Ela temeu pela sua vida e pelos seus filhos. Ela estava nervosa e tomada pelo pânico", concluiu o tribunal."256

Os Tribunais brasileiros ainda têm muita divergência. Ocorre que muitos ainda não chegam a conclusões totalmente justificáveis para absolver essas mulheres e acabam condenando-as. Na verdade, o que se tem visto é que é mais fácil se basear nos fatos acusatórios que provam a culpa da agente do que encontrar indícios de que ela agiu de forma correta ao passar por cima da lei imposta pelo Estado, que condena totalmente essa conduta.

Após 5 horas de julgamento o $1^{\circ}$ Tribunal do Júri de Belém, presidido pelo juiz Edmar Pereira, decidiu pela absolvição de Wilma Ruth Modesto Ferreira, 42 anos, acusada de homicídio praticado contra o companheiro Edilson da Silva Freitas, 48 anos, pedreiro. Por maioria dos votos, o Conselho de Sentença, formado por sete jurados, considerou que a morte se deu em legítima defesa, sustentada pelo promotor de justiça José Rui Barbosa e ratificada pela defesa promovida pelos advogados Antonio Graim Neto e Carlos Figueiredo. ${ }^{257}$

Vê-se que, neste caso, o Tribunal do Júri acolheu a justificativa e absolveu a ré.

Sobre o caso ocorrido na China, se pronunciou o advogado:

Isso significa que casos de violência doméstica, em especial aqueles em que a violência é usada para combater a violência, vão receber maior atenção de diversas partes, especialmente dos tribunais", disse

\footnotetext{
256 Disponível em: <http://www.cmjornal.xl.pt/nacional/portugal/detalhe/absolvidamulher-que-matou-marido.html>. Acesso em: 23 mai. 2015.

257 Disponível em: <http://g1.globo.com/pa/para/noticia/2014/10/mulher-que-matoumarido-e-absolvida-por-legitima-defesa-em-belem.html>. Acesso em: 08 jul. 2015.
} 
Guo, um advogado especialista em direitos das mulheres. $^{258}$

A ideia mais do que bem-vinda do advogado nos alerta para a situação mundial. É preciso que o mundo todo se atente a essas situações, que não param de ocorrer diariamente. Milhares de mulheres são vítimas, mas quando os papéis se invertem e o agressor se torna a vítima, o Estado se descontrola e não sabe ainda como julgar.

\section{CONSIDERAÇÕES FINAIS}

Todo o trabalho desenvolvido mostrou que este assunto tem grandes contradições, e um exemplo disso é o último capítulo, que aborda os casos já ocorridos e algumas decisões já proferidas. Entre elas, vimos que existem os tribunais que preferem absolver e outros que preferem condenar. Dos que condenam, sua grande maioria acaba por impor penas menores, pois, querendo ou não, percebem os motivos pelos quais as mulheres cometem esses crimes.

Além disso, percebe-se que a maioria das mulheres que agem dessa forma, o faz após muitos anos sofrendo nas mãos de seus companheiros agressores, portanto, todas elas já têm uma idade mais avançada, sendo algumas delas já idosas, o que nos mostra claramente o desespero que viveram ao longo de anos.

Outra consideração importante a ressaltar é a de que essas mulheres cometem o crime não só para se livrarem de seu próprio desespero, mas também do de seus filhos. Vê-se que elas sofrem nas mãos de maridos alcoólatras, usuários de drogas e até mesmo loucos, e que eles, além de as agredirem frequentemente, também agrediam seus filhos.

Conclui-se que as duas principais motivações dessas mulheres ao cometerem os crimes, são o desenvolvimento de um transtorno psiquiátrico e a legítima defesa putativa.

No transtorno psiquiátrico, estudou-se que a mulher poderia ter se tornado portadora de uma doença chamada neurose de angústia, desenvolvida ao longo dos anos devido a tantos abusos e agressões.

${ }^{258}$ Disponível em: <http://br.reuters.com/article/worldNews/idBRKBN0EZ1MJ20140624

$>$. Acesso em: 30 jul. 2015. 
Já na legítima defesa putativa, concluiu-se que ela agiria acreditando estar sendo agredida pelo companheiro no momento do crime ou que ele estaria na iminência de fazê-lo.

Explicitou-se como, ao longo dos séculos, as mulheres têm sido vistas pela sociedade, quais suas lutas e suas conquistas mais significantes. Fez-se uma viagem histórica sobre as revoluções feministas em geral e, com isso, se concluiu que muitas das decisões tomadas hoje em dia pelos tribunais são devidas a esse preconceito tão relevante diante do sexo feminino.

Para finalizar, tratou-se de renomados casos propícios ao tema, casos em que as mulheres mataram seus maridos a sangue frio, casos atuais e antigos, nacionais e internacionais. Constatou-se que, em grande parte deles, elas sofreram por muitos anos, e que o assassinato foi totalmente justificado por isso. Em seus depoimentos, elas dizem ter tirado o peso do sofrimento. Além disso, todas confessaram seus crimes, muitas delas, inclusive, foram à delegacia para informar o ocorrido ou ligaram para a polícia imediatamente após o homicídio. Percebe-se aqui que elas não têm perfil de criminosas, pelo contrário, vêm de uma vida sem antecedentes criminais, mas as circunstâncias pelas quais passaram as levaram a cometer o crime.

Como último ponto importante, ressalta-se que em praticamente todos os casos elas já haviam feito denúncias à polícia das agressões que sofriam, mas nenhuma solução foi tomada, gerando assim, cada vez mais, a fúria e um desgaste emocional infinito. Concluiu-se, diante deste fato, que as mulheres estudadas não tiveram outra escolha e encontraram em sua atitude a única saída para acabar com o sofrimento.

Após a análise dos casos, vê-se que, em suma, grande parte dos tribunais acolheu as justificativas dessas mulheres, absolvendo-as ou diminuindo suas penas.

A pesquisa exposta nos mostra um mundo pouco conhecido, pois sempre acabamos por abordar apenas situações como o homicídio passional ou o homicídio ocorrido pelo lado oposto, qual seja o do homem em relação à mulher. Portanto, é de grande importância o assunto abordado, para que saibamos o que ocorre na cabeça dessas mulheres e como a sociedade - e principalmente a justiça - têm lidado com isso, além de expor novas considerações para os pesquisadores e juristas. 


\section{REFERÊNCIAS BIBLIOGRÁFICAS}

ALVES, Branca Moreira; PITANGUY, Jacqueline. O que é feminismo. Coleção Primeiros Passos. São Paulo: Editora Brasiliense, 1981.

Aposentada que esquartejou o marido deixa a cadeia. Disponível em: <http://jmonline.com.br/novo/?noticias,91,SENTINELA,107754>. Acesso em 30 jun. 2015.

BEBIANO, Adriana. Da vida das mulheres infames. A história segundo Emma Donoghue. Anglo-Saxónica Revista do Centro de Estudos Anglísticos da Universidade de Lisboa. Coimbra, 2009. Série II, No. 27, pp.17-32.

. O sexo do desejo: Margaret Atwood reescreve Penélope. Em Cármen Soares (org.), Norma e Transgressão. Coimbra: Faculdade de Letras. 2008.

BINA, Ricardo. Medicina Legal. 2. ed. São Paulo: Saraiva, 2009.

BOURDIEU, Pierre. A dominação masculina. Tradução Maria Helena Kuhner. Rio de Janeiro. Best Bolso, 2014.

CAPEZ, Fernando. Curso de Direito Penal, volume 1: parte geral (arts. $1^{\circ}$ a 120). 11. ed. rev. e atual. São Paulo: Saraiva, 2007.

Caso Yoki: Elize vai a júri popular por matar e esquartejar Matsunaga. Disponível em: <http://noticias.terra.com.br/brasil/ policia/caso-yoki-elize-vai-a-juri-popular-por-matar-e-esquartejarmatsunaga,3035448935480410VgnVCM5000009ccceb0aRCRD.ht $\mathrm{ml}>$. Acesso em 16 abr. 2015.

Correio da manhã. Absolvida mulher que matou marido - Portugal. Disponível em: <http://www.cmjornal.xl.pt/nacional/portugal/ detalhe/absolvida-mulher-que-matou-marido.html>. Acesso em 23 mai. 2015.

CROCE, Delton. Manual de Medicina Legal. 4. ed. São Paulo: Saraiva, 1998.

DELMANTO, Celso. Código Penal Comentado. Atualizado e ampliado por Roberto Delmanto. 3. ed. Renovar, 1991.

DEL, Priore Mary. A mulher na história do Brasil. 4. ed. São Paulo. Contexto, 1994.

FILHO, Nestor Sampaio Penteado. Manual Esquemático de Criminologia. 2. ed. São Paulo: Saraiva, 2012.

JESUS, Damásio de. Direito penal: parte geral. 32. ed. São Paulo: Saraiva, 2011. v. 1. 
Legislação sobre violência contra as mulheres no mundo. Disponível em: <http://www.compromissoeatitude.org.br/legislacao-sobreviolencia-contra-as-mulheres-no-mundo/> Acesso em 09 abr. 2015.

MARINHO, Alexandre Araripe, FREITAS, André Guilherme Tavares de. Manual de Direito Penal - parte geral. Rio de janeiro: Lumen júris, 2009.

Matou marido agressor e foi absolvida. Disponível em: $<$ http://www.dn.pt/inicio/interior.aspx?content_id=658629>. Acess o em 19 jun. 2015.

MAURACH, Reinhart. Tratado de derecho penal, trad. Juan Córdoba Roda, Barcelona. Ed. Ariel, 1962, v. 2.

MIRABETE, Julio Fabrini. FABRINI, Renato N. Manual de Direito Penal: parte geral, arts. $1^{\circ}$ a 120 do CP. 30. ed. São Paulo: Atlas 2014. v. 1.

Mulheres são vistas como propriedades dos homens no Líbano. Disponível em: <http://g1.globo.com/fantastico/noticia/2014/06/mulheres-saovistas-como-propriedades-dos-homens-no-libano.html>. Acesso em 12 mai. 2015.

Mulher mata marido após anos de abuso e indiferença da polícia. Disponível em:

<http://noticias.uol.com.br/inter/efe/2003/12/04/ult1807u498.jhtm> . Acesso em 09 abr. 2015.

Mulher mata marido com fio de ferro de passar roupa em São Vicente. Disponível em: $<$ http://www.atribuna.com.br/noticias/noticiasdetalhe/policia/mulher-mata-o-marido-com-fio-de-ferro-de-passarroupa-em-saovicente/?cHash $=61968 \mathrm{~d} 6 \mathrm{c} 01 \mathrm{c} 7 \mathrm{~b} 0 \mathrm{e} 63 \mathrm{~b} 3 \mathrm{~d} 04 \mathrm{~b} 6884 \mathrm{c} 3512>$. Acesso em 27 abr. 2015.

Mulher que matou marido após ser espancada recebe apoio de outras vítimas. Disponível em: $<$ http://www.pragmatismopolitico.com.br/2015/07/mulher-quematou-marido-apos-ser-espancada-recebe-apoio-de-outrasvitimas.html>. Acesso em 02 jul. 2015.

Mulher que matou marido é absolvida por legítima defesa, em Belém. Disponível em: <http://g1.globo.com/pa/para/noticia/2014/10/mulher-que-matou- 
marido-e-absolvida-por-legitima-defesa-em-belem.html>. Acesso em 08 jun. 2015.

Mulher que sofria violência doméstica mata o marido queimado em Ipira. Disponível

em:

<http://www.ndonline.com.br/florianopolis/noticias/33355-mulherque-sofria-violencia-domestica-mata-o-marido-queimado-emipira.html>. Acesso em 22 jun. 2015.

Mulher reage contra agressão, mata o marido e foge com ajuda de vizinhos. Disponível em: <http://g1.globo.com/sp/santosregiao/noticia/2015/06/mulher-reage-durante-agressao-mata-omarido-e-foge-com-ajuda-de-vizinhos.html>. Acesso em 28 abr. 2015.

NETTO, Ângelo Pressotto. A Psicologia das deficiências mentais. 2. ed. Franca: Unifran, 1979.

Neuroses. O que saber basicamente sobre elas? Disponível em: <http://www.abc.med.br/p/psicologia..47.psiquiatria/220200/neuro ses+o+que+saber+basicamente+sobre+elas.htm>. Acesso em 20 fev. 2015.

NOTÍCIAS REGIONAIS: Em Minas Gerais mulher mata o marido, esquarteja e joga os restos dentro de uma fossa. Disponível em: $<$ http://www.portilhoonline.com.br/noticias-regionaisem-minasgerais-mulher-mata-o-marido-esquarteja-e-joga-os-restos-dentrode-uma-fossa-mae-vai-buscar-filho-de-05-meses-em-crecheparticular-de-caldas-novas-e-recebe-crianca-cheia-d/>. Acesso em 30 jun. 2015.

PALOMBA, Guido Arturo. Loucura e Crime. São Paulo: Fiuza, 1996.

RUELA, Natália. Feminismo e Construção de Identidades Femininas: As Meninas de Lygia Fagundes Telles. Universidade Estadual do Marigá. 2009.

SAGRADA, Bíblia. Gênesis (3, 16). 1989.

SANTOS, Washington dos. Dicionário Jurídico Brasileiro. Belo Horizonte: Del Rey, 2001.

SPRENGER, Jacques. Malleus maleficarum: manual de base do caçador de bruxas. Final do séc. XV. In ALVES, Branca Moreira; PITANGUY, Jacqueline. O que é feminismo. Coleção Primeiros Passos. São Paulo: Editora Brasiliense, 1981.

Supremo Tribunal Chinês suspende pena de morte de vítima de violência doméstica.

Disponível

em: 
<http://br.reuters.com/article/worldNews/idBRKBN0EZ1MJ20140 624>. Acesso em 08 mar. 2015.

TJ-ES - Apelação Criminal : ACR 24050216563 ES 24050216563. Disponível em: <http://tjes.jusbrasil.com.br/jurisprudencia/21397672/apelacao-criminalacr-24050216563-es-24050216563-tjes>. Acesso em 30 mai. 2015. TOLEDO, Francisco de Assis. Princípios básicos de direito penal: de acordo com a Lei n. 7.209, de 11-7-1984 e com a Constituição Federal de 1988. 5. ed. - São Paulo: Saraiva, 1994.

VERNANT, Jean Pierre. O Universo, Os Deuses, Os homens. Tradução: Rosa Freire D'Aguiar - São Paulo. Companhia das Letras, 2000.

XAVIER, Elódia. Que Corpo é esse? O corpo no imaginário feminino. Rio de Janeiro: Editora Mulheres, 2007.

ZIMERMAN, David E. Fundamentos psicanalíticos [recurso eletrônico]: teoria, técnica e clínica: uma abordagem didática. Porto Alegre: Artmed, 2007. 